\title{
Low-carbohydrate diet in type 2 diabetes. Stable improvement of bodyweight and glycemic control during 22 months follow-up Jørgen Vesti Nielsen* and Eva Joensson
}

\author{
Address: Department of Medicine, Blekingesjukhuset, Karlshamn. 37480 Karlshamn, Sweden \\ Email: Jørgen Vesti Nielsen* - jorgen.vesti-nielsen@ltblekinge.se; Eva Joensson - eva-a.jonsson@ltblekinge.se \\ * Corresponding author
}

Published: I 4 June 2006

Nutrition \& Metabolism 2006, 3:22 doi:10.1 I86/1743-7075-3-22
Received: 06 March 2006

Accepted: 14 June 2006

This article is available from: http://www.nutritionandmetabolism.com/content/3/1/22

(C) 2006 Nielsen and Joensson; licensee BioMed Central Ltd.

This is an Open Access article distributed under the terms of the Creative Commons Attribution License (http://creativecommons.org/licenses/by/2.0), which permits unrestricted use, distribution, and reproduction in any medium, provided the original work is properly cited.

\begin{abstract}
Background: Low-carbohydrate diets in the management of obese patients with type 2 diabetes seem intuitively attractive due to their potent antihyperglycemic effect.

We previously reported that a $20 \%$ carbohydrate diet was significantly superior to a 55-60\% carbohydrate diet with regard to bodyweight and glycemic control in 2 non-randomised groups of obese diabetes patients observed closely over 6 months. The effect beyond 6 months of reduced carbohydrate has not been previously reported. The objective of the present study, therefore, was to determine to what degree the changes among the 16 patients in the low-carbohydrate diet group at 6-months were preserved or changed 22 months after start, even without close followup. In addition, we report that, after the 6 month observation period, two thirds of the patients in the high-carbohydrate changed their diet. This group also showed improvement in bodyweight and glycemic control.
\end{abstract}

Method: Retrospective follow-up of previously studied subjects on a low carbohydrate diet.

Results: The mean bodyweight at the start of the initial study was $100.6 \pm 14.7 \mathrm{~kg}$. At six months it was $89.2 \pm 14.3 \mathrm{~kg}$. From 6 to 22 months, mean bodyweight had increased by $2.7 \pm 4.2 \mathrm{~kg}$ to an average of $92.0 \pm 14.0 \mathrm{~kg}$. Seven of the 16 patients $(44 \%)$ retained the same bodyweight from 6 to 22 months or reduced it further; all but one had lower weight at 22 months than at the beginning. Initial mean $\mathrm{HbAlc}$ was $8.0 \pm \mathrm{I} .5 \%$. After 6 and 12 months it was $6.6 \pm 1.0 \%$ and $7.0 \pm 1.3 \%$, respectively. At 22 months, it was still $6.9 \pm 1.1 \%$.

Conclusion: Advice on a $20 \%$ carbohydrate diet with some caloric restriction to obese patients with type 2 diabetes has lasting effect on bodyweight and glycemic control.

\section{Background}

We previously reported that 16 obese patients with type 2 diabetes, who were advised to lower their carbohydrate intake to $20 \%$, over 6 months achieved significantly better control of hyperglycemia and bodyweight than a control group of similar patients $(\mathrm{n}=15)$, advised to follow the official dietary guidelines where 55-60\% carbohy- drate is recommended [1]. We have now reviewed the clinical charts after 22 months and present the data for the patients. Since two-thirds of the controls at some point have changed diet, we report here mainly the results for the $20 \%$-carbohydrate group with regard to glycemic control (HbA1c), bodyweight, body mass index (BMI) $(\mathrm{kg} /$ $\mathrm{m}^{2}$ ) and lipids after 22 months. We also report HbA1c and 
bodyweight for the 7 patients who immediately switched to a $20 \%$ carbohydrate diet from the original low-fat diet, and for whom long-term data is available

\section{Methods}

The method has previously been described in detail [1]. In short, the patients - free of thyroid illness, manifest cardiac and renal disease - were advised to follow a diet containing initially $1800 \mathrm{kcal}$ for men and $1600 \mathrm{kcal}$ for women. The proportions of carbohydrates, protein and fat were $20 \%, 30 \%$ and $50 \%$ respectively. The daily quantity of carbohydrates was 80-90 g. The recommended carbohydrate consumption was limited to vegetables and salad. Instead of ordinary bread crisp/hard bread was recommended, each slice containing 3.5 to $8 \mathrm{~g}$ carbohydrates. Excluded were bread, pasta, potatoes, rice and breakfast cereals. The patients were counselled to not eat between meals. It was further recommended that they walk 30 minutes a day and take a daily multivitamin supplement containing extra calcium. There was an introductory meeting lasting most of a day. The subjects were then followed closely for 6 months.

The controls were initially advised on a diet with about the same caloric content, but the proportions of carbohydrates, protein and fat were 55-60\%, $15 \%$ and 25-30\% respectively [1]. In the normal diabetes diet whole-grain products are recommended. Generous helpings of vegetables and several servings of fruits as snacks between meals are also recommended. As a number of the controls attended our normal diabetes educational course as introduction to the observation period, the control group on average received about $50 \%$ more attention - measured in hours - than the low-carbohydrate group. The controls then proceeded in the same way as the low-carbohydrate group.

Seven of the controls switched to a $20 \%$ carbohydrate diet immediately after the follow-up period. For those we have data 12-14 months after the change. Three more have later sought information and have changed diet. We have no long-term data for those. Five of the original controls have not changed diet.

All the patients were known to us and visited the diabetes nurse regularly after the initial period. The same scales and laboratory were used for all measurements. The present report is a review of clinical charts. Where a figure is missing at 22 months we have taken the mean from the two closest figures. Means are given with standard deviations. T-test for dependent samples is used.

\section{Results}

Table 1 shows the measured parameters from start to 22 months.

\section{Bodyweight}

The mean weight has increased from month 6 to month 22 by $2.7 \pm 4.2 \mathrm{~kg}$. Seven of the 16 patients retained the same bodyweight from 6 to 22 months or reduced it further (See Figure 1).

\section{HbAlc}

Initial mean HbA1c for the low carbohydrate group was $8.0 \pm 1.5 \%$. After 6 months the value was $6.6 \pm 1.0 \%$ and, after 12 months, $7.0 \pm 1.3 \%$ (normal HbA1c $<5.6 \%$ in non-diabetic persons).

The mean HbA1c for the group has been stable since the 12 month mark. At 22 months mean HbA1c was $6.9 \pm 1.1$ $\%$ and 4 patients displayed an HbA1c below $6.0 \%$ whereas initially only one person did so.

The HbA1c reduction occurred independently of the weight reduction as seen in Figure 2 where the relationship between percentage reduction of weight and HbA1c after 3 months is shown $(r=-0.30)$.

\section{Medications}

An important feature of carbohydrate restriction as a treatment for type 2 diabetes is that reduction or elimination of medication is often possible $[8,21,22]$. At the start of this study, 15 of the 16 patients used metformin and 5 sulfonylurea (SU). Eleven patients were insulin-treated. The mean daily insulin dosage was $60 \pm 33 \mathrm{IU} /$ day.

At the end of the 6-months $20 \%$-carbohydrate period 2 persons had discontinued SU and 3 had reduced the doses. Three subjects had discontinued insulin and the mean insulin requirement among the last 8 persons had fallen to $18 \pm 11 \mathrm{IU} /$ day.

Over the next 16 months 2 persons have again started insulin treatment following an increased intake of carbohydrates. The mean requirement of the 11 persons is $27 \pm$ 21 IU/day.

Fourteen subjects used antihypertensive medications. Five reduced the medications during the first 6 months and have not increased them again. The mean blood pressure has been unchanged. Six of the patients used statins. There has been no change.

\section{The cross-over of the 7 controls}

The 7 controls were followed for 2 periods of 6 months separated by a gap of 2 months. As shown in Table 2, reduction of bodyweight and $\mathrm{HbA} 1 \mathrm{c}$ in the low-fat period was $3.5 \pm 3.5 \mathrm{~kg}$ and $0.9 \pm 0.8 \%$ respectively. Both bodyweight and HbA1c increased slightly in the 2 month gap period but the change to a low-carbohydrate diet led to a mean reduction of bodyweight during the $20 \%$-carbohy- 
Table I: Effect of diet on weight, BMI, HbAlc and fasting lipids. Sixteen obese patients with type 2 diabetes started at month 0 on a diet with the proportions: $20 \%$ carbohydrates, $30 \%$ protein and $50 \%$ fat. The figures shown are before, 3, 6 and 22 months after the dietary change

\begin{tabular}{|c|c|c|c|c|c|c|c|}
\hline Months & 0 & 3 & $\mathbf{P} *$ & 6 & $\mathbf{P *}$ & 22 & $\mathbf{P *}$ \\
\hline Weight (kg) & $100.6 \pm 14.7$ & $91.9 \pm 14.7$ & $<0.001$ & $89.2 \pm 14.3$ & $<0.001$ & $92.0 \pm 14.0$ & $<0.001$ \\
\hline BMI $\left(\mathrm{kg} / \mathrm{m}^{2}\right)$ & $36.1 \pm 4.2$ & $33.0 \pm 4.5$ & $<0.001$ & $32.0 \pm 4.3$ & $<0.001$ & $32.9 \pm 3.5$ & $<0.001$ \\
\hline $\begin{array}{l}\text { HbAIc (\%) } \\
\text { Lipids (mmol/l) }\end{array}$ & $8.0 \pm 1.5$ & $5.9 \pm 0.7$ & $<0.001$ & $6.6 \pm 1.0$ & $<0.001$ & $6.9 \pm 1.1$ & $<0.001$ \\
\hline Tot-Chol. & $5.6 \pm 1.2$ & $5.8 \pm 1.1$ & 0.4 & $6.1 \pm 1.1$ & 0.06 & $5.7 \pm 1.2$ & 0.9 \\
\hline HDL-Chol. & $\mathbf{I} . \mathbf{I} \pm 0.2$ & $1.2 \pm 0.2$ & $<0.002$ & $1.3 \pm 0.2$ & $<0.001$ & $1.3 \pm 0.3$ & $<0.001$ \\
\hline$\S$ Triglycerides & $1.4(I ; I, 8)$ & $1.2(0.8 ; 1,4$ & 0.01 & I.4(0.9;1.7) & 0.4 & $1.4(1.2 ; 1.9)$ & 0.9 \\
\hline Chol/HDL & $5.4 \pm 1.5$ & $5.0 \pm 1.5$ & 0.02 & $5.0 \pm 1.7$ & 0.07 & $4.6 \pm 1.6$ & $<0.001$ \\
\hline$\S$ TG/HDL & I.4(0.9;1.7) & I.0(0.6;1.2) & 0.003 & $\mathbf{I . 0}(0.7 ; 1.5)$ & 0.03 & $1.3(0.8 ; 1.5)$ & 0.2 \\
\hline
\end{tabular}

$\S$ given as median with 25 and 75 percentiles. * $\mathrm{p}$ values are for differences from baseline.

drate period of $7.5 \pm 6.4 \mathrm{~kg}$ and of HbA1c of $0.9 \pm 1.1 \%$ (range: 0-2.4). The weight and HbA1c achieved during the $20 \%$ carbohydrate period were retained over the following 6 months (see Table 2).

For the five controls, who never changed diet, there was no average change over the 18-22 months.

\section{Discussion}

The short-term effectiveness of low-carbohydrate diets for weight reduction is well established [2-6]. Weight reduction is primarily caused by decreased caloric intake [2-6] although decreased energy efficiency has also been found [7]. A high-starch, high-carbohydrate diet excessively

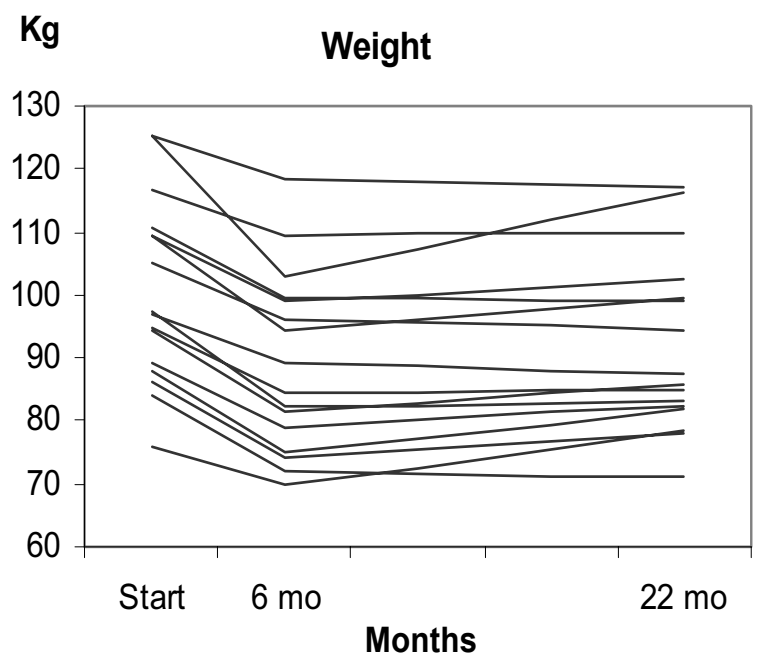

Figure I

Individual changes in bodyweight in 16 obese patients with type 2 diabetes. The patients at start changed from a high-carbohydrate diet to a diet consisting of $20 \%$ carbohydrates, $30 \%$ protein and $50 \%$ fat. stimulates appetite and disturbs energy balance in patients with the metabolic syndrome and type 2 diabetes [8]. A reduction of carbohydrates normalises the balance, reduces insulin concentrations and favours utilization of stored fat as fuel as well as significantly reducing insulin resistance [8]. Weight loss in overweight persons is improved by a higher proportion of protein, presumably due to protein's effect on satiety and/or metabolic efficiency $[7,9-11]$. A reduction in carbohydrates for patients with type 2 diabetes effectively reduces both fasting and postprandial glucose as well as HbA1c. These effects can be independent of weight loss $[8,12,13]$.

Critics of the low-carbohydrate dietary approach usually point to the lack of long-term studies. The change of diet described here in combination with the usual diabetes care has produced long periods of increased well-being in

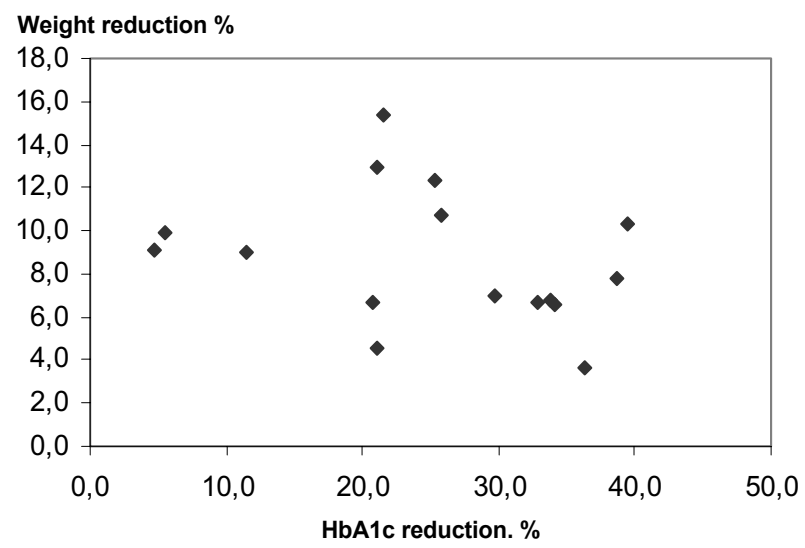

Figure 2

Percentage changes in HbAlc and bodyweight in 16 obese patients with type 2 diabetes. The figures are plotted 3 months after a change to a $20 \%$ carbohydrate diet at which time the reduction in $\mathrm{HbAlc}$ was most pronounced. 
Table 2: Changes for the low fat group during cross-over to low carbohydrate

\begin{tabular}{llll}
\hline Intervention & Month & Weight change $(\mathrm{kg})$ & HbAlc \% \\
\hline Low-fat & $\mathbf{I - 6}$ & $\mathbf{- 3 . 5} \pm 3.5$ (range: 0 to -9$)$ & $\mathbf{- 0 . 9} \pm 0.8$ (range: -0.4 to -1.8 \\
Gap & $\mathbf{7 - 8}$ & $\mathbf{0 . 5} \pm 1.6$ & $\mathbf{0 . 3} \pm 0.3$ \\
Low CHO & $\mathbf{9 - 1 4}$ & $\mathbf{- 7 . 5} \pm 6.4$ (range: 0 to -20$)$ & $\mathbf{- 0 . 9} \pm 1.1$ (range: 0 to -2.4$)$ \\
& & $\mathbf{M e a n}$ Weight $(\mathrm{kg})$ & $\mathbf{M e a n ~ H b A l c ( \% )}$ \\
Low-CHO & $\mathbf{1 5}$ & $\mathbf{8 9 . 2} \pm 15.9$ & $\mathbf{5 . 7} \pm 0.8$ \\
& $\mathbf{2 2}$ & $\mathbf{9 0 . 2} \pm 15.5$ & $\mathbf{5 . 7} \pm 0.9$
\end{tabular}

§given as median with 25 and 75 percentiles. $* \mathrm{p}$ values are for differences from baseline.

these patients. It is significant that $44 \%$ of the patients have had a stable weight or have reduced it further and all but one had a lower weight at 22 months than at the beginning of the study. Twenty-five $\%$ of the patients had previously been dieting continuously and another $50 \%$ had tried to lose weight many times. The reasons they gave for not continuing their previous weight loss programs were 1) constant hunger, and 2) no effect on bodyweight despite strict calorie counting and fat reduction. The lack of hunger and cravings with the low-carbohydrate diet may be an important reason for their present success.

Regular self measurement of blood glucose has probably made it possible for these patients to succeed. Self determination of blood glucose provides a feed-back mechanism and may be another reason that $44 \%$ of the patients succeeded in maintaining their weight.

For most insulin-treated patients, we found that it was necessary to be one step ahead in lowering the insulin doses, that is, if weight loss stopped, and the patient was adhering to the diet (as judged by blood glucose values), even a minor reduction of the insulin dose normally resulted in continued weight loss and presumably continued motivation. This close supervision may be another reason for the patients' initial success.

Improved HbA1c is associated with a reduced incidence of microvascular and macrovascular complications [14-16]. The original low carbohydrate group had maintained a significantly lower mean HbA1c for almost 2 years and a reduced vascular morbidity might therefore be expected in this group. Similarly, intentional weight loss in type 2 diabetes patients is associated with a reduced mortality of $30-40 \%$ [17]. For the average patient each $1 \mathrm{~kg}$ weight loss is associated with 3-4 months prolonged survival [18] making it likely that the patients described here have achieved a survival benefit.

At some point following a reduction of bodyweight and insulin resistance, a decrease of cardiovascular risk would be expected $[19,20]$. We have examined the medical charts for both the original high-carbohydrate group and the low-carbohydrate group from 3 months after the initi- ation of the diet therapy - when an effect might be detected - and forward for episodes of cardiovascular disease. Three episodes of cardiovascular disease have occurred among the 5 patients that never changed diet. The 16 patients in the low-carbohydrate diet group (19 months observation time) and the 7 from the high-carbohydrate diet group that changed diet (10 months observation time) - totalling 23 patients - have been free of cardiovascular disease during the follow-up period ( $\mathrm{p}<$ 0.03. Fischer Exact).

Several recent reviews have made the case for reducing the carbohydrate load in type 2 diabetes [21-23] or metabolic syndrome [24] and the low-carbohydrate diet presented here is clearly effective in many obese people with type 2 diabetes. Because of its effectiveness it should be used with close clinical supervision in patients on insulin or oral hypoglycaemic agents.

In summary, a reduced carbohydrate diet is an effective tool in the management in motivated obese patients with type 2 diabetes. The effect is generally retained after almost 2 years. There has been no evidence of a negative cardiovascular effect among the 16 subjects.

\section{Competing interests}

The author(s) declare that they have no competing interests.

\section{Authors' contributions}

JVN wrote the manuscript and analysed the data. Both authors collected data and gave final approval to the manuscript.

\section{Acknowledgements}

We thank Peter Naeser, MD, PhD for reading the manuscript and for valuable suggestions.

\section{References}

I. Nielsen JV, Jonsson E, Nilsson AK: Lasting improvement of hyperglycaemia and bodyweight: low-carbohydrate diet in type 2 diabetes. Ups J Med Sci 2005, I I 0(2): 179-83.

2. Samaha FF, lqbal N, Seshadri P, Chicano KL, Daily DA, McGrory J, Williams T, Gracely EJ, Stern L: A low-carbohydrate as compared with a low-fat diet in severe obesity. N Eng J Med 2003, 348:2074-8I. 
3. Foster GD, Wyatt HR, Hill JO, McGuckin BG, Brill C, Mohammed BS, Szapary PG, Rader DJ, Edman JS: A randomized trial of low-carbohydrate diet for obesity. N Eng J Med 2003, 348:2082-90.

4. Brehm JB, Seeley RJ, Daniels SR, D'Alessio DA: A randomised trial comparing a very low carbohydrate diet and calorierestricted low fat diet on body weight and cardiovascular risk factors in healthy women. J Clin Endocrinol 2003, 88:1617-1623.

5. Sondike SB, Copperman N, Jacobson MS: Effects of a low-carbohydrate diet on weight loss and cardiovascular risk factors in overweight adolescents. J Pediatr 2003, 142:253-8.

6. Yancy WS, Olsen MK, Guyton JR, Bakst RP, Westman EC: A lowcarbohydrate ketogenic diet versus a low-fat diet to treat obesity and hyperlipidemia. Ann Int Med 2004, 140:769-777.

7. Krieger JW, Sitren HS, Daniels MJ, Langkamp-Henken B: Effects of variation in protein and carbohydrate intake on body mass and composition during energy restriction: a meta-regression. Am J Clin Nutr 2006, 83(2):260-74.

8. Boden G, Sargrad K, Homko C, Mozzoli M, Stein TP: Effects of a low- carbohydrate diet on appetite, blood glucose levels, and insulin resistance in obese patients with type 2 . diabetes. Ann Intern Med 2005, I 42:403-4I I.

9. Skov AR, Toubro S, Ronn B, Holm L, Astrup A: Randomized trial on protein vs. carbohydrates in ad libitum fat reduced diet for the treatment of obesity. Int J Obes Relat Metab Disord 1999, 23(5):528-36.

10. Dumesnil JG, Turgeon J, Tremblay A, Poirier P, Gilbert M, Gagnon L, St-Pierre S, Garneau C, Lemieux I, Pascot A, Bergeron J, Despres JP: Effect of a low-glycemic index - low-fat - high protein diet on the atherogenic risk profile of abdominal obese men. BrJ Nutr 200I, 86:557-568.

11. Stubbs RJ, van Wyk MC, Johnstone AM, Harbron CG: Breakfast high protein, fat or carbohydrates: effect on within-day appetite and energy balance. Eur J Clin Nutr 1996, 50(7):409-17.

12. Gutierrez M, Akhavan M, Jovanovic L, Peterson CM: Utility of a short-term $25 \%$ carbohydrate diet on improving glycemic control in type 2 diabetes mellitus. J Am Coll Nutr 1998, I 7(6):595-60.

13. Gannon MC, Nuttall FQ: Effect of a high-protein, low-carbohydrate diet on blood glucose control in people with type 2 diabetes. Diabetes 2004, 53:2375-2382.

14. The Diabetes Control and Complications Trial Research Group: The effect of intensive treatment of diabetes on the development and progression of long- term complications in insulindependent diabetes mellitus. N Engl J Med 1993, 329:977-986.

15. The diabetes control and complications trial/epidemiology of diabetes interventions and complications (DCCT/EDIC) study research group: Intensive diabetes treatment and cardiovascular disease in patients with type I diabetes. N Eng J Med 2005, 353:2643-2653.

16. UK Prospective Diabetes Study (UKPDS) Group: Intensive bloodglucose control with sulphonylureas or insulin compared with conventional treatment and risk of complications in patients with type 2 diabetes (UKPDS 33). Lancet 1998, 352(9 I 3 I ):837-853

17. Williamson DF, Pamuk E, Thun M, Flanders D, Byers T, Heath C: Prospective study of intentional weight loss and mortality in never-smoking overweight US white women aged 40-60 years. Am J Epidemiol 1995, I 4 I: I I 28-4I.

18. Lean ME, Powrie JK, Anderson AS, Garthwaite PH: Obesity, weight loss and prognosis in type 2 diabetes. Diabetic Medicine 1990, 7:228-233

19. Straznicky NE, Lambert EA, Lambert GW, Masuo K, Esler MD, Nestl PJ: Effects of dietary weight loss on sympathetic activity and cardiac risk factors associated with the metabolic syndrome. I Clin Endocrinol Metab 2005, 90( I I ):5998-6005.

20. Park SH, Shim KW: Reduction in visceral adiposity is highly related to improvement in vascular endothelial dysfunction among obese women: an assessment of endothelial function by radial artery pulse wave analysis. Yonsei Med J 2005, 46(4):5II-18.

21. Kennedy RL, Chokkalingam K, Farschi HR: Nutrition in patients with type 2 diabetes: are low-carbohydrate diets effective, safe or desirable? Diabet Med 2005, 22:82 I-832.

22. Arora SK, McFarlane SI: The case for low carbohydrate diets in diabetes management. Nutrition \& Metabolism 2005, 2:16.
23. Yancy WS Jr, Foy M, Chalecki AM, Vernon MC, Westman EC: A lowcarbohydrate, ketogenic diet to treat type 2 diabetes. Nutr Metab (Lond) 2005, 2:34.

24. Volek JS, Feinman RD: Carbohydrate restriction improves the features of Metabolic Syndrome. Metabolic Syndrome may be defined by the response to carbohydrate restriction. Nutr Metab (Lond) 2005, 2:3I.
Publish with Bio Med Central and every scientist can read your work free of charge

"BioMed Central will be the most significant development for disseminating the results of biomedical research in our lifetime. "

Sir Paul Nurse, Cancer Research UK

Your research papers will be:

- available free of charge to the entire biomedical community

- peer reviewed and published immediately upon acceptance

- cited in PubMed and archived on PubMed Central

- yours - you keep the copyright

Submit your manuscript here:

http://www.biomedcentral.com/info/publishing_adv.asp
BioMedcentral 